\title{
Primotrapa gen. nov., an extinct transitional genus bridging the evolutionary gap between Lythraceae and Trapoideae, from the early Miocene of North China
}

Ya Li $i^{1,2^{*}} \mathbb{B}$, Yi-Ming Cui ${ }^{2}$, Carole T. Gee ${ }^{3,4}$, Xiao-Qing Liang ${ }^{5}$ and Cheng-Sen Li ${ }^{1 *}$

\begin{abstract}
Background: Although Trapa is a well-defined genus of distinctive freshwater plants with accumulations of extensive morphological and embryological autapomorphies, its phylogenetic relationships have long been unclear. Formerly placed in the monotypic family Trapaceae, Trapa is now recognized as sister to Sonneratia within Lythraceae s.l., although both genera lack morphological synapomorphies. Thus, a split between the two taxa must have occurred in deep evolutionary time, which raises the possibility of finding transitional forms in the fossil record.
\end{abstract}

Results: Here we describe a new genus and species, Primotrapa weichangensis Y. Li et C.-S. Li (Lythraceae s.l.: Trapoideae), based on three-dimensionally preserved floral cups, fruits, and seeds from the early Miocene of Weichang County, Hebei Province, China. Primotrapa is characterized by a shallow, saucer-shaped floral cup, four distally barbellate sepals, four intersepal appendages alternating with the sepals at the rim of cup, a superior to basally inferior ovary, a fusiform or ovoid, one-seeded fruit with a ribbed surface, and a long persistent peduncle. Two fossil species of Hemitrapa are proposed as new combinations of Primotrapa, namely P. alpina (T. Su et Z.-K. Zhou) Y. Li et C.-S. Li comb. nov. and P. pomelii (Boulay) Y. Li et C.-S. Li comb. nov. Our phylogenetic analysis based on fifteen flower and fruit characters supports the placement of Primotrapa, Hemitrapa and Trapa in a monophyletic clade, which comprise subfamily Trapoideae. The phylogenetic analysis places Primotrapa at the base of Trapoideae.

Conclusions: In view of its superior ovary, which is a plesiomorphic character of Lythraceae s.l., the newly recognized genus Primotrapa and its three species likely represent transitional forms that bridge the evolutionary gap between the basal taxa of Lythraceae s.l., i.e. Lythrum, and the highly derived taxon Trapa.

Keywords: Water caltrop, Freshwater macrophyte, Extinct aquatic plant, Primotrapa, Trapa, Hemitrapa, Lythraceae, Miocene, Hebei Province, China

\footnotetext{
*Correspondence: yali@nigpas.ac.cn; lics@ibcas.ac.cn

'State Key Laboratory of Systematic and Evolutionary Botany, Institute of Botany, Chinese Academy of Sciences, Beijing 100093, China

Full list of author information is available at the end of the article
}

(c) The Author(s). 2020 Open Access This article is licensed under a Creative Commons Attribution 4.0 International License, which permits use, sharing, adaptation, distribution and reproduction in any medium or format, as long as you give appropriate credit to the original author(s) and the source, provide a link to the Creative Commons licence, and indicate if changes were made. The images or other third party material in this article are included in the article's Creative Commons licence, unless indicated otherwise in a credit line to the material. If material is not included in the article's Creative Commons licence and your intended use is not permitted by statutory regulation or exceeds the permitted use, you will need to obtain permission directly from the copyright holder. To view a copy of this licence, visit http://creativecommons.org/licenses/by/4.0/. The Creative Commons Public Domain Dedication waiver (http://creativecommons.org/publicdomain/zero/1.0/) applies to the data made available in this article, unless otherwise stated in a credit line to the data. 


\section{Backgound}

Trapa L., the water caltrop, is a genus of annual freshwater macrophytes, which grow in sluggish rivers, lakes, swamps, and ponds and are native to the tropical to warm temperate regions of Eurasia and Africa [1, 2]. Trapa has accumulated extensive autapomorphic features such as a unique embryo, leaf margins with characteristic double-mucronate tooth apices, distinctively horned fruits, distally barbellate sepals (horns) (Fig. 1bf), and generally prolate-spheroidal crested pollen [3, 4]. This suite of striking characters led to the assignment of all living species in the genus to the monotypic family Trapaceae $[1,5,6]$. However, the relationship of the Trapaceae to other families has remained unclear. Trapa was once thought to be related to Ludwigia L. (Onagraceae) [7] or Trapella Oliv. (Pedaliaceae) [8], but any morphological similarities have been dismissed as homoplasy (non-homologous similarity) [6, 9]. A close relationship between Trapa and Lythraceae sensu stricto (s.str.) was also proposed, based on fossil evidence [9].

Molecular data unquestionably place Trapa and the other three distinct genera, namely Duabanga Buch.Ham., Punica L., and Sonneratia L.f. in the family Lythraceae sensu lato (s.l.) (Fig. 1g) [10, 12-14]. From a morphological standpoint, Lythraceae s.l. lack morphological synapomorphies to define them, especially in regard to ovary position. It is a superior ovary in Lythraceae s.str., a superior to basally inferior ovary in Sonneratia, a semi-inferior ovary in Duabanga, and a nearly completely inferior ovary in Punica and Trapa [11]. Based on molecular phylogenetics, Trapa and Sonneratia are sister genera $[10,12-14]$, as unlikely as it may seem morphologically (Fig. 1a, b) [11]. Moreover, in regard to habit and habitat, Sonneratia is a tree growing in the brackish waters of mangrove and coastal environments, while annual Trapa is an aquatic plant floating in quiet bodies of freshwater. Hence, a link between Trapa and Sonneratia must exist in their common evolutionary history. Until now, the absence of this link in fossil record has greatly hampered our understanding of the evolutionary position of Trapa within Lythraceae s.l. and has led to a conflict between morphological and molecular systematics $[10,11]$.

While fossil remains of Trapa have been frequently reported from the Miocene swamp deposits of Europe and Asia [15-20], as well as from North America [21-26], unequivocal Trapa fossils first appear in the middle Miocene [2]. Hemitrapa Miki is an extinct genus of

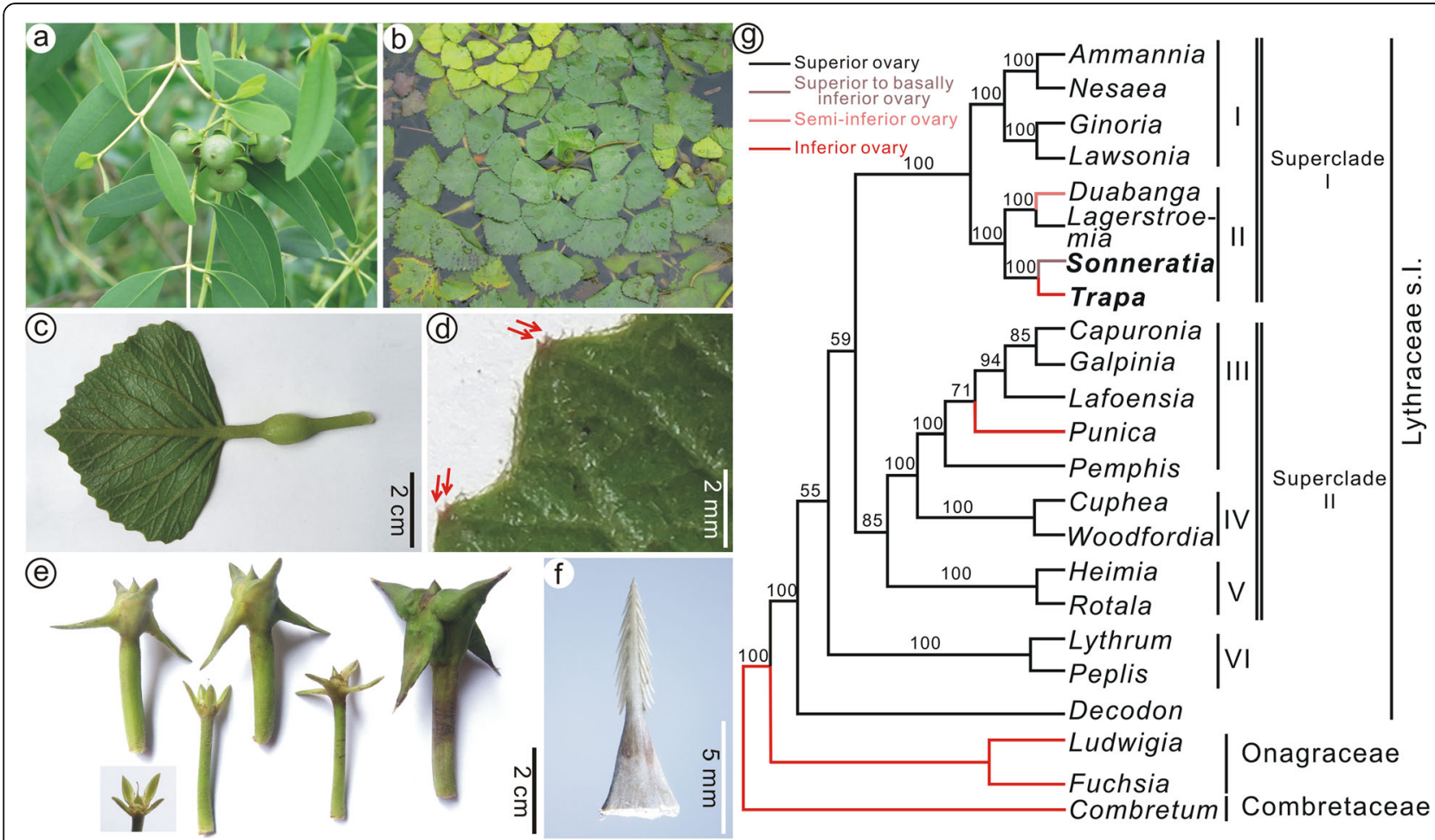

Fig. 1 Extant Sonneratia and Trapa and the phylogenetic relationships of Lythraceae s.l. a Sonneratia apetala Buch.-Ham. from Qi'ao-Dan'gan Island Mangrove Nature Reserve, Zhuhai, Guangdong Province, China. b Trapa natans L. from Xuanwu Lake, Nanjing, Jiangsu Province, China. c, d A leaf of $T$. natans $L$. and an enlargement (d) showing the characteristic double apices of the teeth on the leaf margin (red arrows). e A series of fruits of T. natans showing different developmental stages. f A sepal of T. natans with the cortex removed, showing dital, recurved barbs. $\mathbf{g}$ The position of the ovary in Lythraceae s.l. mapped on the Bayesian 50\% majority-rule consensus of 4000 trees from the combined molecular data of four gene regions $[10,11]$ 
fossil fruits initially described by Miki [17] from the late Miocene of Akazu and Hatagoya, Japan, and is thought to be closely related to Trapa [9]. Hemitrapa fruits are fusiform and contain a semi-inferior ovary. They also occur frequently in other mid-latitude localities in the Miocene of Eurasia and North America [27] and disappear after the Pliocene [2, 27]. Based on comparative morphology, Miki hypothesized that living Trapa evolved from ancestral Lythrum L. through the extinct genus Hemitrapa [9]. However, Miki's hypothesis can no longer be considered tenable, as Trapa and Lythrum share only a family level relationship [2]. While other studies also consider Trapa to be a descendant of Hemitrapa $[4,16]$, it is more likely that Trapa and Hemitrapa share a common ancestor [28]. It is worth pointing out that both Trapa and Hemitrapa are also morphologically very different from other taxa of Lythraceae s.l., including Trapa's molecular genetic sister Sonneratia.

In the present study, we describe a new, extinct member of Lythraceae s.l., Primotrapa weichangensis Y. Li et C.-S. Li gen. et sp. nov., on the basis of threedimensionally preserved floral cups, fruits and seeds from the early Miocene of Weichang County, Hebei Province, China (Fig. 2). A phylogenetic analysis shows that Primotrapa, Hemitrapa, and Trapa form a monophyletic clade, i.e. the subfamily Trapoideae. Phylogenetic analysis also reveals the transitional position of Primotrapa between Sonneratia and Trapa + Hemitrapa clade within Lythraceae s.l. The phytogeography of Primotrapa, its origin, and dispersal through geological time are also discussed.

\section{Results}

\section{Systematic paleontology}

Order: Myrtales Juss. ex Bercht. et J. Presl, 1820

Family: Lythraceae J. St.-Hil., 1805

Subfamily: Trapoideae Voigt, 1845

Genus: Primotrapa Y. Li et C.-S. Li gen. nov.

Generic diagnosis: Flowers perigynous or basally epigynous, bearing a short shallow, saucer-shaped floral cup, persistent on the fruit. Sepals 4, acicular, sparsely barbellate toward apex, inserted on floral axis in the same whorl, curved away from the floral axis, persistent on the fruit. Intersepal appendages 4 , acicular, spiny, dichotomizing once, alternating with sepals at the rim of the cup, detaching from mature fruit. Ovary superior to basally inferior. Fruit fusiform, irregularly dehiscent, oneseeded, with an elongated apex, sparsely ribbed surface, and a long persistent peduncle.

Etymology: The genus name refers to its primitive Trapa-like fruits.

Type species: Primotrapa weichangensis Y. Li et C.-S. Li sp. nov.
Specific diagnosis: Floral cup perigynous with a superior ovary. Fruit fusiform or ovoid in shape, with an elongated and smooth (non-ribbed) apex. Barbs arise at a wide angle to the sepals. Fruit surface finely and sparsely ribbed.

Holotype: PEPB70591 (Fig. 3a).

Paratypes: PEPB70592-70593 (Fig. 3b, c), 7059670598 (Fig. 3d-f), 70601-70607 (Fig. 3g-k, Fig. 4a-d), 70629-70630 (Fig. 4e, f), 70631-70637 (Fig. 5a-g), 70681-70683 (Fig. 5h-j).

Etymology: The species epithet refers to the fossil locality in Weichang County.

Type locality: Guangfayong Town, Weichang County, Hebei Province, China.

Stratigraphy and geological age: Hannuoba Formation, early Miocene.

Repository: National Museum of the Plant History of China, Chinese National Herbarium, Institute of Botany, Chinese Academy of Sciences, Beijing, China.

Description: The floral cups (hypanthia) of these fossil flowers are very short, shallow, saucer-shaped, perigynous, and usually persistent on the fruits (Fig. $3 a-c, g-n$ ); however, some hypanthia are found detached from the immature fruits (Fig. $3 \mathrm{~d}-\mathrm{j}$ ). Sepals are four, acicular, curved outward at about their midpoint, 7-14 mm long and about $1 \mathrm{~mm}$ wide, and sparsely barbellate toward the apex (Figs. 3a-c, g-n, Fig. 4a-e), inserted on the floral axis in the same whorl and arising at a $30-40^{\circ}$ angle. The barbs on the sepals are straight or recurved, forked once or unforked, about 1-2 mm long (Fig. 4e). The intersepal appendages are four, Y-shaped, spiny, dichotomized once, $3-5 \mathrm{~mm}$ long, up to $0.5 \mathrm{~mm}$ wide at their bases, nearly the same length as the apical forks (Fig. 3a, g-j, Fig. 4f), and alternate with the sepals at the rim of the floral cup. The epidermis of the sepals is composed of elongated cells (Fig. $4 \mathrm{~g}-\mathrm{j}$ ). At the bottom of the floral cup is a single superior ovary (Fig. $3 k-n$ ). The pedicel is very long (Fig. 3a-c).

Fruits are small, $7.0-16.0 \mathrm{~mm}$ long, $3.0-4.5 \mathrm{~mm}$ wide, fusiform or ovoid with an elongated apex, obtuse base, sparsely ribbed surface (Fig. $5 \mathrm{a}-\mathrm{g}$ ). Pericarps are thinner and less woody than Trapa. The ribs are probably the remains of a fleshy exocarp, and tightly adnate to the endocarp, acicular, arising longitudinally from the base of the fruit, and extending beyond the broadest part of the fruit, but not reaching the apex of the fruit (Fig. 5d). Sepals are persistent, mostly not barbellate (Fig. 5a-g). Intersepal appendages are absent in mature fruits (Fig. $5 \mathrm{a}-\mathrm{g})$, probably due to abscission. Peduncles are slender, curved and broadening towards the floral cup, up to 4 $\mathrm{cm}$ long, 1-2 $\mathrm{mm}$ wide (Fig. $5 \mathrm{a}-\mathrm{g}$ ). Fruits are likely oneseeded (Fig. 5f) and irregularly dehiscent (Fig. 5b, c, f). Seeds are obovoid or elliptoid, $5.4-7.5 \mathrm{~mm}$ long and $4.9-6.5 \mathrm{~mm}$ wide $($ Fig. $5 \mathrm{~h}-\mathrm{j})$. The surface of the testa 


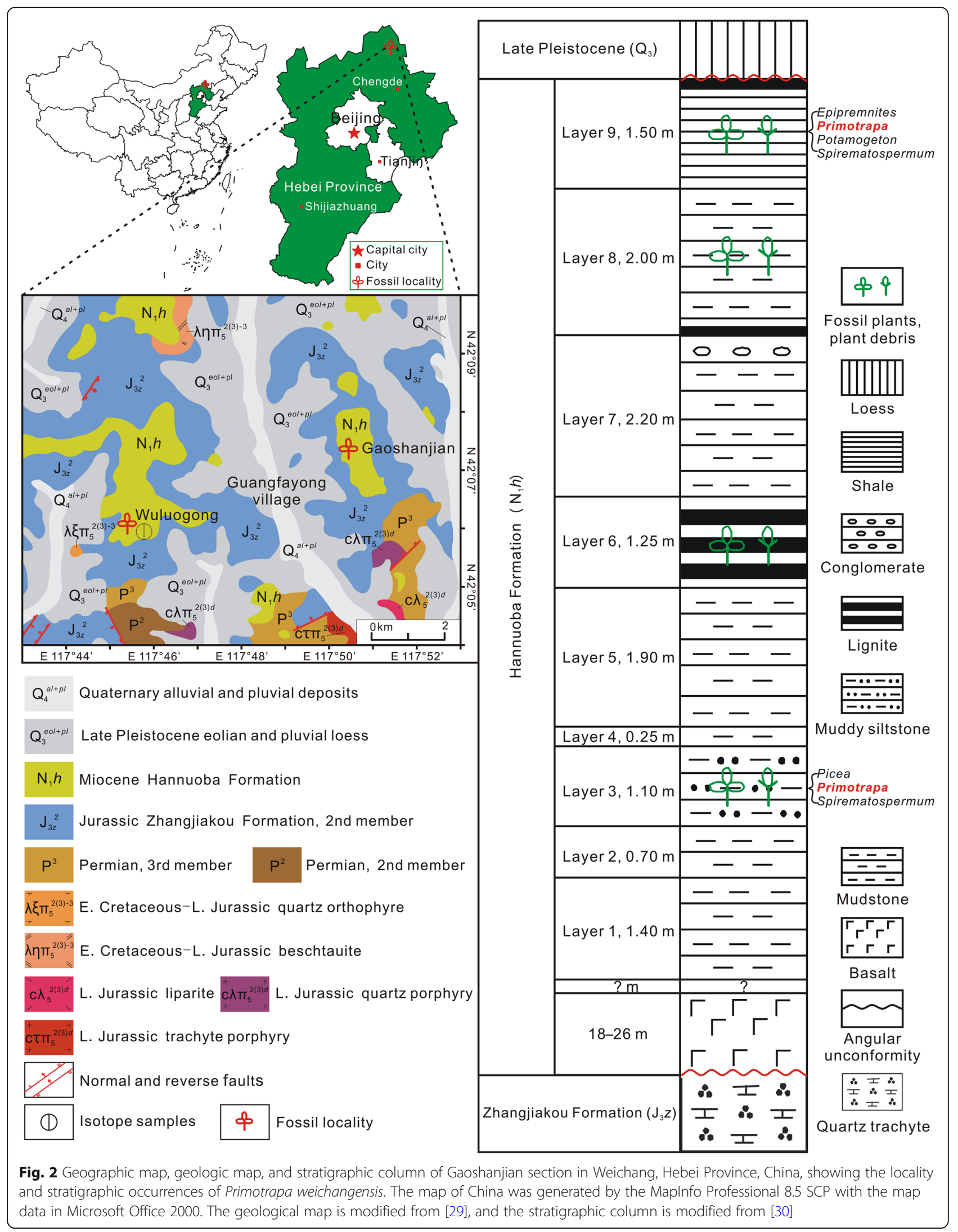



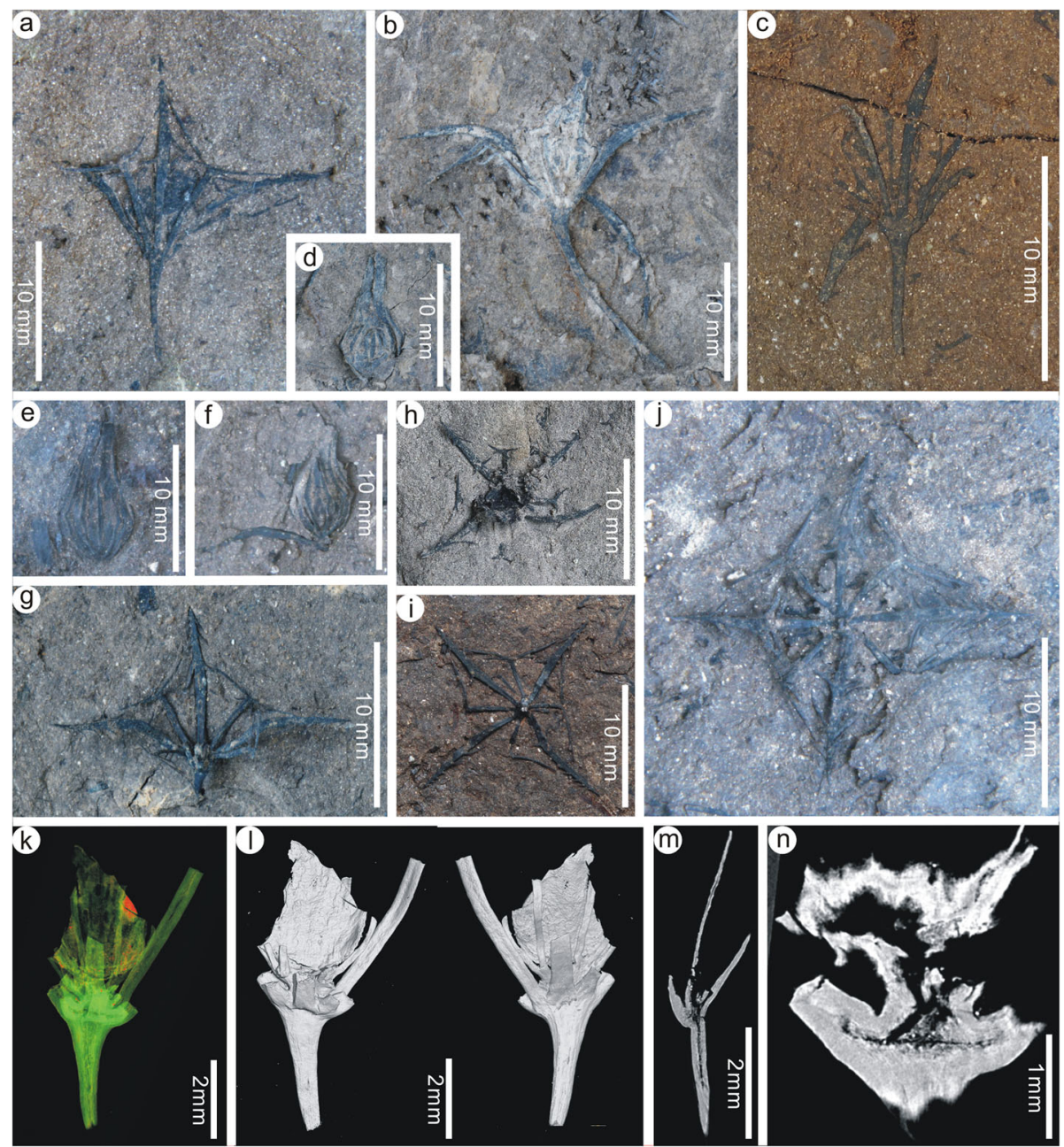

Fig. 3 Floral cups and immature fruits of Primotrapa weichangensis from the Miocene of Weichang, China. a A laterally preserved, immature fruit showing the floral cup with three sepals and three intersepal appendages alternately arranged. PEPB70591 (Holotype). b-c Another two laterally preserved, immature fruits. PEPB70592-70593. d-f Abscised immature fruits showing the ribbed surface. PEPB70596-70598. g-j Laterally, distally, or basally preserved floral cups showing four sepals and four intersepal appendages alternately arranged at the rim of the cup. PEPB70601-70604. kn Micro-CT-scanned, 3-D reconstruction of a floral cup (k) showing the front and back views of the floral cup (I), and the longitudinal sections ( $\mathbf{m}$, n). PEPB70605

consists of irregularly shaped, pentagonal to hexagonal cells (Fig. 5k, l).

\section{Primotrapa pomelii (Boulay) Y. Li et C.-S. Li comb. nov.}

Synonyms:

1878 Carpolithus pomelii Saporta [31], p. 67, nom. inval.

1899 Trapa pomelii Boulay [32], p. 66, pl. 9, figs. 98100

1991 Hemitrapa pomelii (Saporta) Mai [33], p. 102, pl. 13, figs. 6-10

2003 Hemitrapa cf. pomelii (Boulay) Mai [34], fig. 2

Occurrences: $P$. cf. pomelii was reported from the late Eocene diatomite of Kučlín, Czech Republic [34], while $P$. pomelii occurs in the late Oligocene of Rott,
Germany, the early Miocene of Otterwisch, Germany, and the early Miocene of Gergovie, France [32-36].

Remarks: This species represents the oldest fossil species of the subfamily Trapoideae and is morphologically much different from the majority of the species of Hemitrapa. It is transferred here from Hemitrapa to Primotrapa, because its sepals are inserted near the base of the fruit [32-36] as they are in Primotrapa, rather than inserted about mid-length along the fruit as is characteristic for Hemitrapa [9, 17, 27]. The main difference between $P$. pomelii and $P$. weichangensis is that the fruit surface of $P$. pomelii is more ribbed $[32,34,36]$ than $P$. weichangensis (Fig. 5a-g), and the fruit apex gradually narrows distally into a conical structure in $P$. pomelii $[32,34,36]$, instead of the narrowly elongated apex seen 

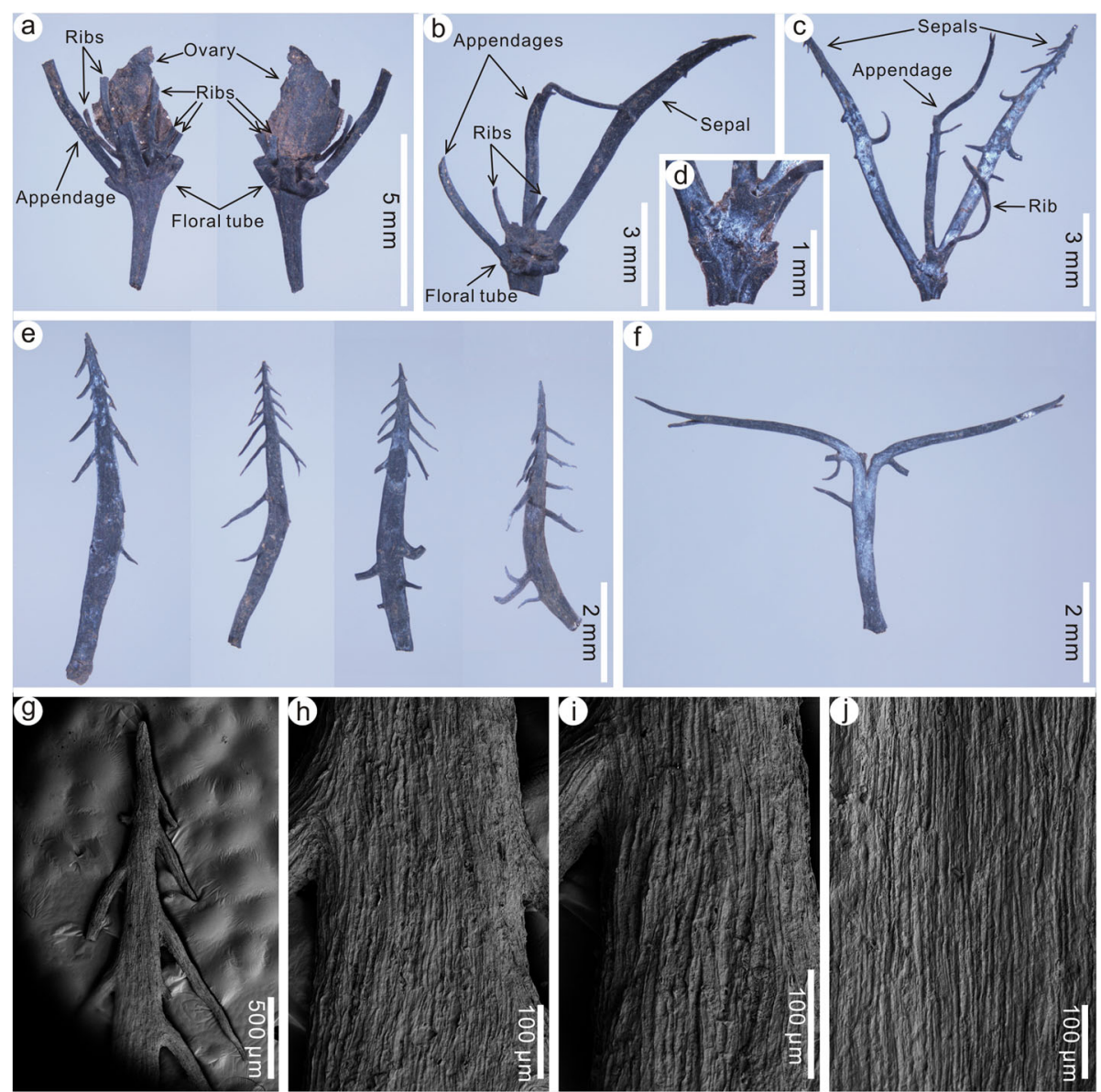

Fig. 4 Floral cups and dispersed sepals and intersepal appendages of Primotrapa weichangensis from the Miocene of Weichang, China. a Front and back views of a floral cup showing the base of the fruit free from the shallow, saucer-shaped floral cup. PEPB70605. b A small saucer-shaped floral cup with remains of the sepals, epicalyx, and fruit ribs. PEPB70606. c-d Longitudinal view of a floral cup (c) and its enlargement (d). PEPB70607. e Four detached, isolated sepals showing sparsely spaced recurved barbs. PEPB70629-1-4. f A detached, isolated intersepal appendage. PEPB70630-1. g-j SEM of a sepal showing its striated surface. PEPB70629-5

in P. weichangensis (Fig. 5a-g). However, some specimens of $P$. pomelii from the late Oligocene of Rott and the early Miocene of Otterwisch, Germany $[33,35,36]$ show definite similiarities to $P$. weichangensis, including some immature fruits with a shallow, saucer-shaped floral cup, as observed in our specimens (Fig. 3e-j). However, the floral cups of the German fossils are very incomplete and lack complete sepals and intersepals, hampering more detailed comparison. Furthermore, the barbs on their sepals are different, arising at a narrow angle to the sepal, as in Trapa (Fig. 1f), whereas in our species the barbs arise at a wide angle to the sepal (Fig. 4e).

Primotrapa alpina (T. Su et Z.-K. Zhou) Y. Li et C.-S. Li comb. nov.

Synonym:

2018 Hemitrapa alpina T. Su et Z.-K. Zhou [37], pl. 2, figs. 1-10
Occurrence: Earliest Oligocene of Kajun, Markam County, Xizang, China.

Remarks: The fruits of Primotrapa alpina are elongate or fusiform in shape and are not borne on persistent peduncles, differentiating them from $P$. pomelii and $P$. weichangensis. However, the absence of a peduncle in $P$. alpina may be due to taphonomic bias or an abscission of a mature fruit from the peduncle at maturity [37]. Most specimens of $P$. alpina possess a basal, inferior ovary, whereas our specimens of $P$. weichangensis each bear a superior ovary. Moreover, the apex of the fruit is finely ribbed and conical in $P$. alpina, while it is not ribbed and narrowly elongated in $P$. weichangensis.

\section{Discussion}

Carpological comparisons with related fossil and extant aquatic taxa

Primotrapa is superficially similar to three Cretaceous genera, i.e. Beipiaoa Dilcher, Sun et Zheng, Palaeotrapa 

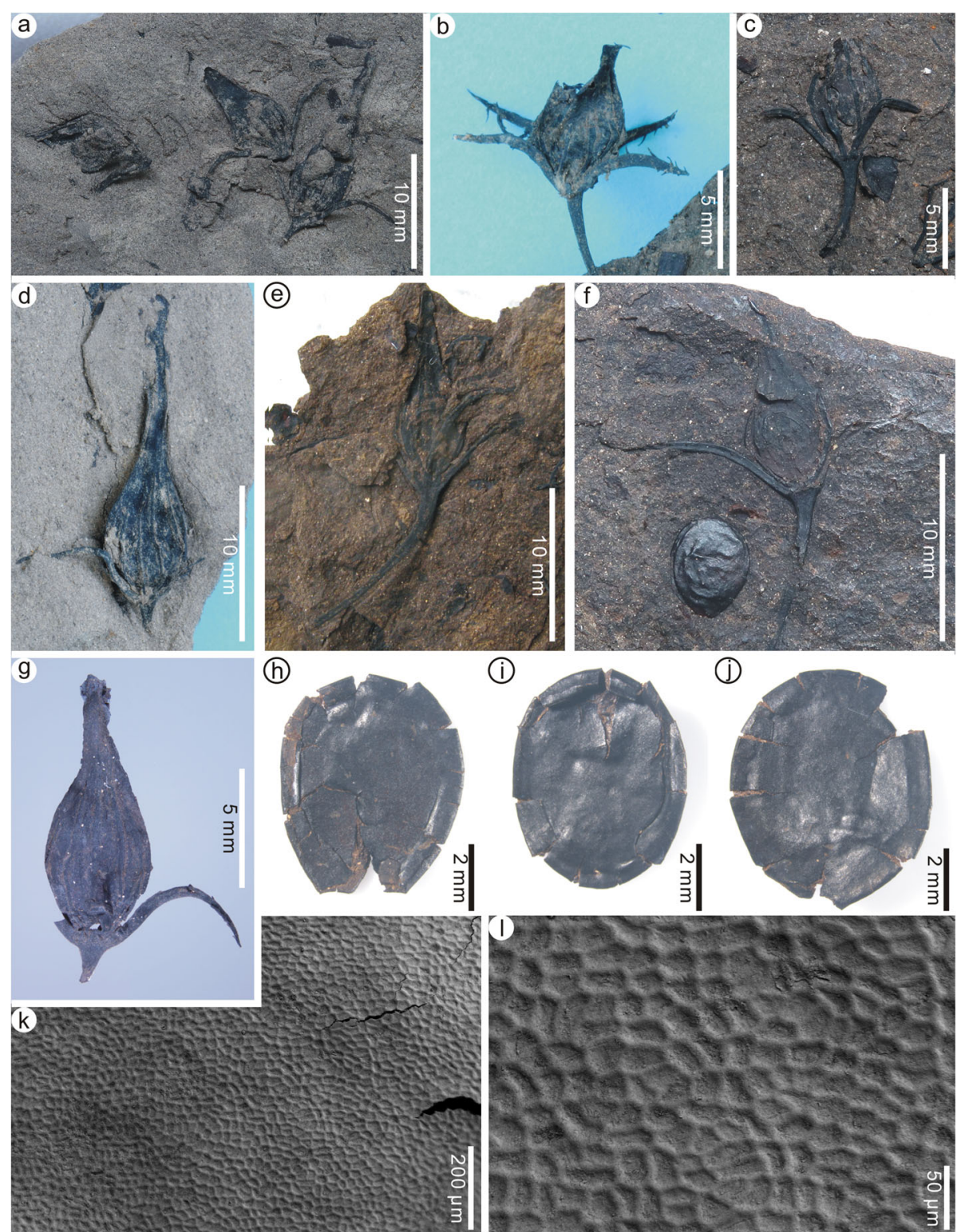

Fig. 5 Fruits and seeds of Primotrapa weichangensis from the Miocene of Weichang, China. a Muddy siltstone with three $P$. weichangensis fruits exposed on the surface. PEPB70631. b-g Laterally compressed fruits, each showing a persistent floral cup with 1-4 remaining sepals, ribbed fruit surface, persistent peduncle, and probably one seed in the fruit (f). PEPB70632-70637. $\mathbf{h}-\mathbf{j}$ Laterally compressed seeds of $P$. weichangensis. PEPB70681-70683. k-I SEM of the seed surface, showing irregularly shaped, pentagonal to hexagonal cells

Golovneva and Prototrapa Vassiljev, each of which consists of three species [38-40]. Beipiaoa is characterized by having apically three- or four-horned fruits, which were reported from the Early Cretaceous Yixian Formation of Beipiao, Liaoning, China [39, 41] (Fig. 6a-c). Palaeotrapa is represented by two-horned fruits found in association with Quereuxia leaves in the Maastrichtian of the Koryak Upland, Russia [38] (Fig. 6d-f). Prototrapa was established for very small fruits (only 1-3 mm long) with two long horns from the Aptian-Albian of southeastern Australia [40] (Fig. 6g-i). Beipiaoa,
Palaeotrapa, and Prototrapa all have horned Trapa-like fruits with a poorly developed fruit head and a distinctive fruit body [27], but they lack barbellate sepals, intersepal appendages, and finely ribbed fruit surface, which differentiate all these three genera from Primotrapa. The fruit of Trapa is also quite dissimilar to these three genera $[2,27,34]$.

Instead, Primotrapa more closely resembles the nowextinct, Cenozoic genus Hemitrapa, as they both have fusiform fruits with a persistent floral cup, four distally barbellate sepals and four intersepal appendages 


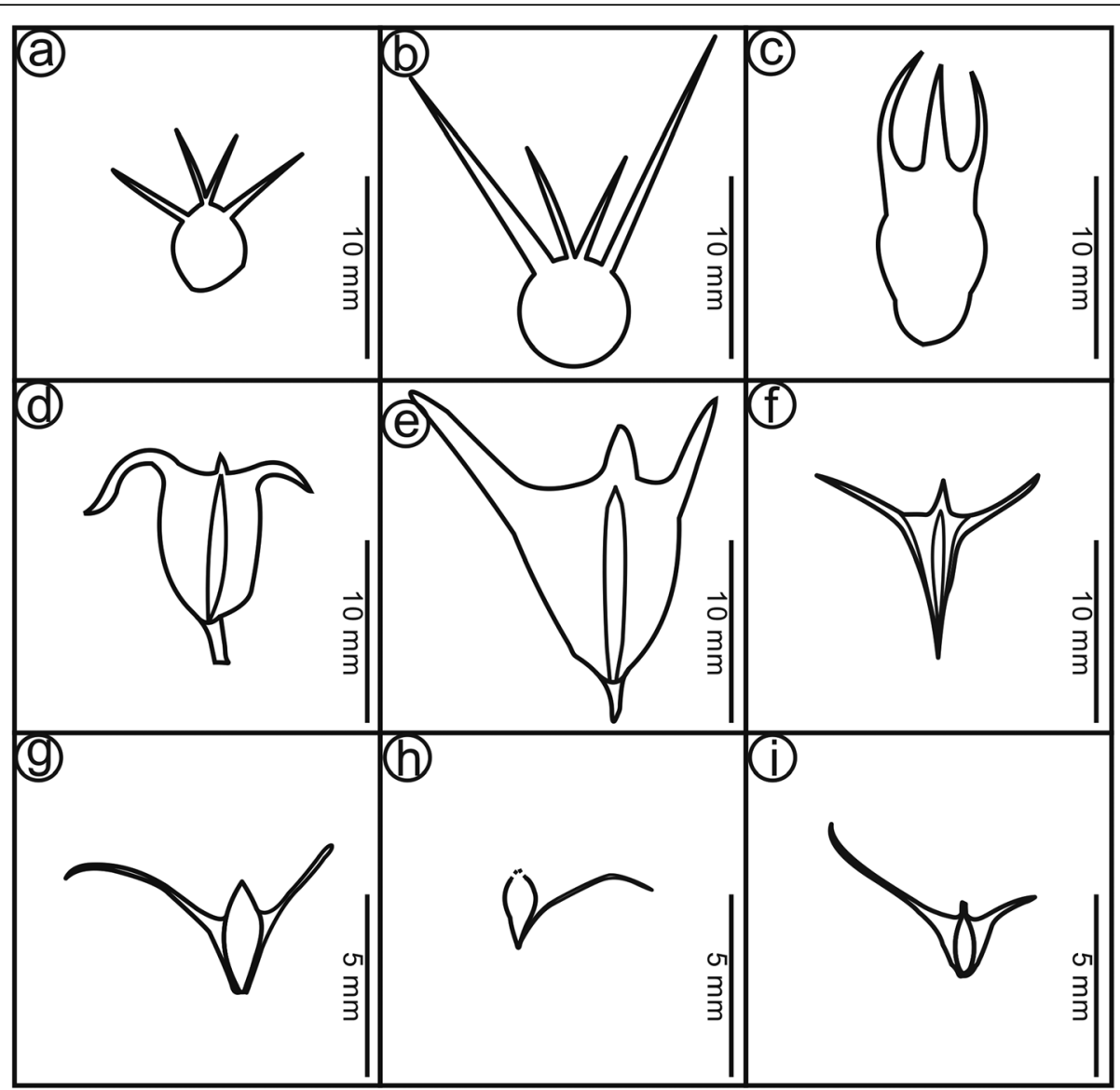

Fig. 6 Line drawings of the fruits of the genera Beipiaoa, Palaeotrapa and Prototrapa. a-c Beipiaoa parva Dilcher, Sun et Zheng (a), B. rotunda Dilcher, Sun et Zheng (b), and B. spinosa Dilcher, Sun et Zheng (c) from the Early Cretaceous Yixian Formation of Beipiao, Liaoning, China [39]. d-f Palaeotrapa aculeata (Krysht.) Golovn. (d), Palaeotrapa bicornata Golovn. (e), and Palaeotrapa triangulata Golovn. (f) from the Late Cretaceous of the Koryak Upland, Russia [38]. g-i Prototrapa douglasii V. Vassiljev (g), Prototrapa praepomelii V. Vassiljev (h), and Prototrapa tenuirostrata V. Vassiljev (i) from the Early Cretaceous of southeastern Australia [40]

arranged alternately at the rim of the floral cup, a less woody pericarp, a ribbed surface (Primotrapa) or a striated protrusion (the exserted portion) of the fruit (Hemitrapa), and a long, persistent peduncle. However, they differ in that Primotrapa has a very small, shallow, saucer-shaped floral cup, a superior to basally inferior ovary, and Y-shaped intersepal appendages, while Hemitrapa possesses a bowl-shaped floral cup, a semi-inferior ovary, and spine-like intersepal appendages (Fig. 7).

When compared with the fruits of extant aquatic plants, Primotrapa superficially resembles Ceratophyllum L. (Ceratophyllaceae) in having a similarly-sized, fusiform fruit with an elongated apex. However, Ceratophyllum differs in having two long basal spines and sometimes two more spines on the upper part of the fruit [43]. Primotrapa is similar to Nymphoides Ség. (Menyanthaceae) in having a perigynous floral cup deeply lobed to near its base, a superior ovary, and a long persistent peduncle. However, Nymphoides has (4or) 5-merous flowers without intersepal appendages, and few-seeded capsular fruits [44].

Primotrapa is similar to Trapa in a series of characters, such as a persistent floral cup, four distally barbellate sepals and four intersepal appendages arranged alternately at the rim of the cup, and a ribbed fruit surface [42] (Figs. 1, 7). The main differences between Primotrapa and Trapa are that the former has a very small, shallow, saucer-shaped floral cup with a superior to basally inferior ovary, four sepals in the same level, Yshaped intersepal appendages, and a long persistent peduncle, whereas the latter has a epigynous floral cup with a nearly completely inferior ovary, four sepals that initiate at the same level and later develop into 0 to 2 pairs of horns (sepals) at different levels, tubercle-like intersepal appendages (sometimes absent), and a sessile mature fruit with a distinctly contacted fruit neck (Figs. 1, 7). In summary, the fruit of Primotrapa is morphologically 


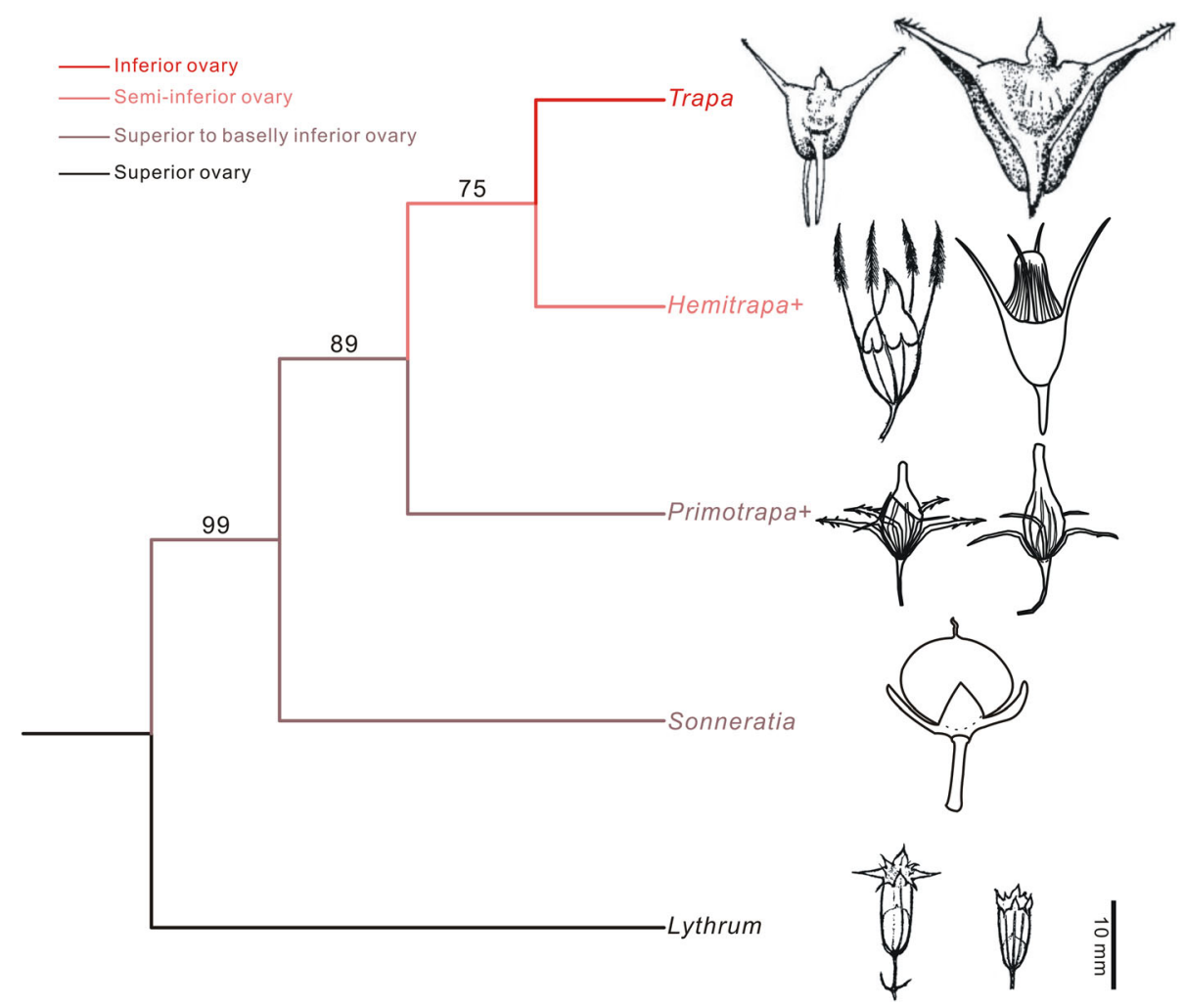

Fig. 7 MP 50\% Majority-rule consensus of 1416 trees and the line drawings of the fruits. Tree length =19, Consistency Index $(C \mid)=0.947$, Retention Index $(R I)=0.900$, Rescaled Consistency Index $(R C)=0.853$. Bootstrap values (50\%) are above the branches. + indicates extinct genera. Scale bars $=10 \mathrm{~mm}$ for all fruits. The fruit of Trapa is represented by the extant species T. incisa Siebold et Zucc. on the left and T. natans $L$. on the right, both modified from Flora of China Editorial Committee [42]; Hemitrapa is represented by the type species H. trapelloidea Miki on the left, modified from Miki [9], and by the Chinese species H. shanwangensis Wang on the right, modified from Wang [27]; Primotrapa weichangensis is represented by an immature fruit on the left and a mature fruit on the right; Sonneratia is represented by the extant species $S$. apetala Buch.Ham, drawn from Fig. 1a; Lythrum is represented by the fossil species L. tetrasepalum Miki on the left and the extant species $L$. anceps (Koehne) Makino on the right, both modified from Miki [9]

most similar to those of the extinct genus Hemitrapa and the living genus Trapa.

\section{Phylogeny and evolution of Primotrapa within Lythraceae}

s.l.

Our morphological phylogenetic analysis places Primotrapa, Hemitrapa, and Trapa in the monophyletic subfamily Trapoideae (Fig. 7). It also suggests that Primotrapa is the basal taxon of the subfamily, sister to a Hemitrapa + Trapa clade (Fig. 7). Derivation of Sonneratia and Trapoideae from a common ancestor is strongly supported by molecular evidence [10, 12-14] (Figs. 1, 7). As in Primotrapa, Sonneratia also has a superior to basally inferior ovary, which suggests that this type of ovary is a plesiomorphic character for Sonneratia and the Trapoideae.

Lythrum, an early-branching genus of Lythraceae s.l. (Fig. 1g), has 6-merous flowers [11]; however, a fossil Lythrum with 4-merous flowers was described from the late Miocene of Akazu and Obata, Japan, which was considered to represent a form ancestral to Hemitrapa [9]. In having a superior ovary, which is a plesiomorphic character of Lythraceae s.l. [10], P. weichangensis is potentially basal to Primotrapa and may also represent an example with primitive morphology of basal Lythraceae s.l. Interestingly, our investigation of the ontogeny of the fruit in extant Trapa (Fig. 1f) reveals that it has a nearly semi-inferior ovary in its early developmental stages, which gradually becomes nearly completely inferior as fruit matures. Thus, the ontogenetic development of Trapa fruit appears to reflect the phylogeny of the Trapoideae.

\section{Phytogeographic history of Primotrapa}

The oldest fossils of Primotrapa appear in the late Eocene diatomite of Kučlín, Czech Republic [34], then during the Oligocene, Primotrapa appears in Xizang, China [37], and Rott, Germany [33]. By the early Miocene, Primotrapa had spread to Otterwisch, Germany [33], Gergovie, France [32, 33], and Weichang, China (this paper). 
Overall, this pattern suggests that the genus likely originated during the Eocene of Eurasia, remaining restricted to the mid-latitudes of Europe and East Asia during the mid-Cenozoic (Fig. 8), then becoming extinct after the early Miocene. However, the last surviving member of subfamily Trapoideae, Trapa, has a broad current Old World distribution (Fig. 8). Similarly, its sister genus Sonneratia grows in Old World mangrove communities from East Africa to Indo-Malesia, Australia, New Guinea, and the West Pacific islands [11, 45] (Fig. 8).

\section{Conclusions}

Primotrapa weichangensis Y. Li et C.-S. Li (Lythraceae s.l.: Trapoideae) is described as a new genus and species based on three-dimensionally preserved floral cups, fruits and seeds from the early Miocene of Weichang, Hebei Province, China. Two additional taxa are transferred to the new genus: $P$. pomelii (Boulay) Y. Li et C.S. Li comb. nov. and P. alpina (T. Su et Z.-K. Zhou) Y.
Li et C.-S. Li comb. nov. The close morphological similarity of Primotrapa, Hemitrapa and Trapa suggests a close evolutionary relationship within subfamily Trapoideae rather than convergent evolution, with morphological cladistic analysis placing Primotrapa as sister to the remainder of subfamily Trapoideae. In view of its superior ovary, a plesiomorphic character of Lythraceae s.l., Primotrapa seems to be intermediate between basal Lythraceae s.l. taxa (e.g. Lythrum) and more highly derived genera such as Trapa.

\section{Methods}

\section{Geological setting}

The fossil plant material described here was all collected from an outcrop at the Gaoshanjian locality $\left(42^{\circ} 07^{\prime} 33^{\prime \prime}\right.$ N, 117 50'28" E; $1406 \pm 16$ m), near Guangfayong Town, Weichang County, Chengde City, Hebei Province, China (Fig. 2). Collecting of fossils does not need any permits in this area. The outcrop consists of nine layers of

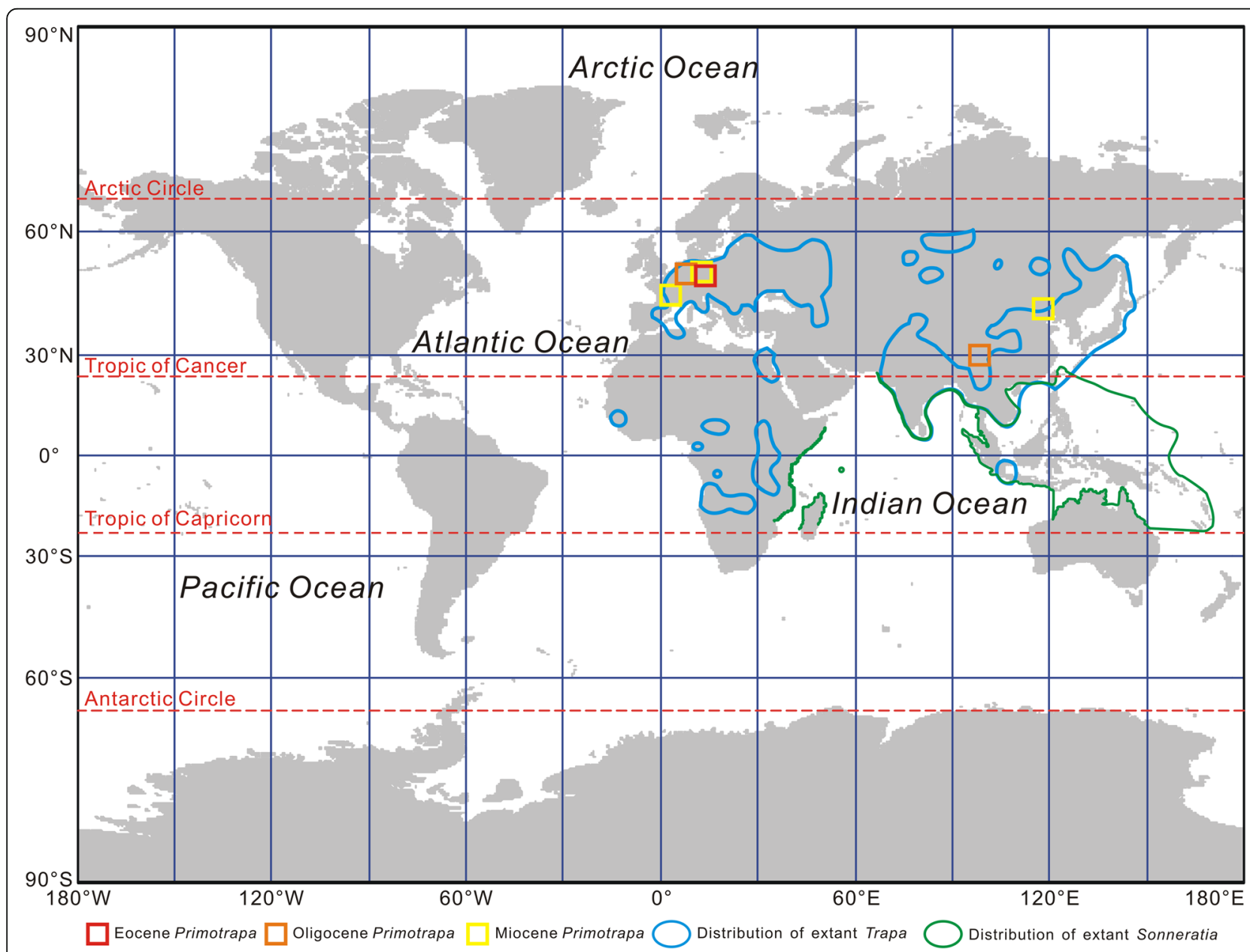

Fig. 8 Distribution of fossil Primotrapa, as well as extant Trapa and Sonneratia, on a world map with Miller cylindrical projection. The base map is from https://www.naturalearthdata.com/. Fossil sites were plotted on the map using Maplnfo Professional 8.5 SCP. The present-day distribution range of living Trapa and Sonneratia were modified from Mai [35] and Mao and Foong [45] 
lacustrine deposits (Fig. 2). The sedimentary rock and its underlying basalts belong to the Hannuoba Formation, according to the 1: 200,000 geological map of Qipanshan section (K-50-16) [29]. Fossil specimens of Primotrapa were collected from the third (muddy siltstone) and ninth layers (shale) (Fig. 2).

The age of Hannuoba Formation was originally assigned to the Miocene, based on the correlation with the presence of fossil mammals (Monosaulax changpeiensis $\mathrm{Li}$ and Lagomorpha gen. et sp. indet.) from Wafangyingzi, Zhangbei County, Hebei Province [46]. Later, it was re-interpreted as early Miocene based on plant fossils and sporopollen assemblages, as well as by $\mathrm{K}-\mathrm{Ar}$ radiometric dating of the basalt $(22.1 \mathrm{Ma})$ from Wuluogong, near Guangfayong Town [29]. Megafossils of mosses, e.g. Leptodictyum, Drepanocladus, and Amblystegium (Amblystegiaceae), conifers, e.g. Pinus, Picea, and Tsuga (Pinaceae), and angiosperms, e.g. Comptonia (Myricaceae), Weigela (Caprifoliaceae), Scirpus (Cyperaceae), and Spirematospermum (Zingiberaceae) have been described from the Miocene of Gaoshanjian [47-51]. Palynological investigation suggests a warm temperate mixed forest of conifers and broad-leaved trees with a few subtropical elements [30].

\section{Fossil preparation, photography and repository}

The fossil remains of Primotrapa are charcoalified, and preserved as compressions in a matrix of muddy siltstone and lignite. They were exposed from the matrix by the technique of dégagement [52]. Selected specimens were treated with $10 \% \mathrm{HCl}$ and $48 \% \mathrm{HF}$, and then rinsed with water and air dried. Specimens were imaged using a digital camera (Canon PowerShot G15), a stereomicroscope (ZEISS SteREO Discovery.V20), scanning electron microscope (LEO1530VP), and a Micro-CT (ZEISS Xradia520 Versa). In total, 40 floral cups, many detached sepals and intersepal appendages, 50 fruits, and 20 seeds were assigned the inventory numbers PEPB70591-70700 and deposited at the National Museum of the Plant History of China, Chinese National Herbarium, Institute of Botany, Chinese Academy of Sciences in Beijing. Ya Li and Cheng-Sen Li carried out the formal identification of the samples and provided details of the voucher specimens deposited.

\section{Morphological phylogenetic analysis}

To reconstruct the phylogenetic relationship of Primotrapa, three extant genera and two fossil genera of Lythraceae s.l. were chosen for cladistic analysis, employing a morphological matrix of 15 characters (Tables 1 and 2). Lythrum was chosen as the outgroup because it is a basal member of the superclade I of the family (Fig. 1g), according to molecular phylogenetic results of Lythraceae s.l. [10]. Since the relationships among the extant genera could not be resolved by morphological data alone [10], the backbone constraint tree approach was used to determine the phylogenetic position of Primotrapa. The constrained tree is modified from the Bayesian tree of the combined molecular data proposed by Graham et al. [10]. All characters were unordered and equally weighted, except one character, namely, the position of the ovary. This character is considered to be irreversible, because a superior ovary is plesiomorphic in Lythraceae s.l., and semi-inferior to

Table 1 Character Coding for Morphological Analysis

\begin{tabular}{|c|c|}
\hline Character & Codes \\
\hline 1. Merosity & $0=4 ; 1=6$ \\
\hline 2. Sepal barbs & $0=$ absent $; 1=$ present \\
\hline 3. Hypanthium shape & $0=$ cup-shaped; 1 = tube-shaped \\
\hline 4. Calyx lobe length ${ }^{a}$ & $0=$ half or more of total floral cup/tube length; $1=$ less than half of total floral cup/tube length \\
\hline 5. Hypanthium: carpel & $0=$ less than $1 / 2 ; 1=$ ca. $1 / 2$ or more \\
\hline 6. Pollen shape ${ }^{a}$ & $0=$ prolate to prolate-spheroidal; 1 = oblate to oblate-spheroidal \\
\hline 7. Pollen pseudocolpi ${ }^{\mathrm{a}}$ & $0=$ absent; 1 = 3 pseudocolpi; 2 = 6 pseudocolpi \\
\hline 8. Pollen exine sculpture ${ }^{a}$ & $0=$ psilate-scabrate to verrucate; 1 = striate \\
\hline 9. Ovary position & $0=$ superior; $1=$ superior to basally inferior; $2=$ semi-inferior; $3=$ inferior \\
\hline 10. Fruit type ${ }^{a}$ & $0=$ capsule; 1 = berry; 2 = drupaceous \\
\hline 11. Fruit surface ribs & $0=$ absent; $1=$ present \\
\hline 12. Fruit neck & $0=$ absent $; 1=$ present \\
\hline 13. Seed number per fruit & $0=$ numerous; 1 = one-seeded \\
\hline 14. Seed compression ${ }^{a}$ & $0=$ not compressed; $1=$ slightly to strongly compressed \\
\hline 15. Pedicel & $0=$ persistent; $1=$ detached \\
\hline
\end{tabular}

Note: ${ }^{a}$ indicates characters and codes cited from Graham et al. [10] 
Table 2 Morphological Data Matrix

\begin{tabular}{|c|c|c|c|c|c|c|c|c|c|c|c|c|c|c|c|}
\hline Taxon & $1^{\mathrm{a}}$ & 2 & 3 & $4^{a}$ & 5 & $6^{a}$ & $7^{a}$ & $8^{a}$ & 9 & $10^{a}$ & 11 & 12 & 13 & $14^{a}$ & 15 \\
\hline Hemitrapa & 0 & 1 & 0 & 0 & 1 & 1 & 0 & 0 & 2 & 2 & 1 & 0 & 1 & 0 & 0 \\
\hline Lythrum & 1 & 0 & 1 & 1 & 1 & 01 & 1 & 1 & 0 & 0 & 0 & 0 & 0 & 1 & 0 \\
\hline Primotrapa & 0 & 1 & 0 & 0 & 0 & $?$ & $?$ & $?$ & 1 & 2 & 1 & 0 & 1 & 0 & 0 \\
\hline Sonneratia & 0 & 0 & 0 & 0 & 0 & 0 & 1 & 0 & 1 & 1 & 0 & 0 & 0 & 1 & 0 \\
\hline Trapa & 0 & 1 & 0 & 0 & 1 & 1 & 0 & 0 & 3 & 2 & 1 & 1 & 1 & 0 & 1 \\
\hline
\end{tabular}

Note: See Table 1 for codes. ? = missing data; ${ }^{a}$ indicates character matrix cited from Graham et al. [10]

inferior ovaries are secondarily derived [10]. Maximum parsimony (MP) analysis was run in PAUP* 4.0a167 [53] using heuristic search algorithms with random addition (RA), 1000 replicates holding 1 tree at each step, tree bisection and reconnection (TBR) branch swapping and MULTREES settings, with the steepest descent option off. Bootstrap values were calculated from 10 replicates and RA sequences with 1000 replicates holding one tree.

\section{Abbreviations}

s.l.: Sensu lato; s.str: Sensu stricto; TBR: Tree bisection and reconnection; RA: Random addition; CT: Computer tomography

\section{Acknowledgments}

We highly appreciate the anonymous reviewers for their helpful and insightful comments and careful corrections of the language that greatly improved the manuscript. We are grateful to Prof. Steven Manchester (University of Florida), Prof. Zhen-Yu Li (Institute of Botany, Chinese Academy of Sciences), and Prof. Wen-Bo Liao (Sun Yat-sen University) for giving helpful suggestions on the identification, to Dr. Qi Wang, Dr. Natalya Nosova, and Dr. Lutz Kunzmann for providing useful literature. We thank Dr. Jian Yang and Dr. Jin-Feng Li for their help in the field in August 2012. Thanks also go to Su-Ping Wu (Nanjing Institute of Geology and Palaeontology, Chinese Academy of Sciences) for assisting with micro-CT.

\section{Authors' contributions}

C-SL and $Y L$ designed the study. $Y L, X-Q L$, and C-SL collected the fossils. $Y L$ conducted the experiments and prepared the figures. $Y L$ and $Y-M C$ carried out the morphological cladistic analysis. YL wrote the manuscript. CTG significantly improved the understandability of the manuscript. All authors discussed the results, read, and approved the final manuscript.

\section{Funding}

This work was supported by the National Natural Science Foundation of China (Grant Nos. 41502017 and 31760057), the Strategic Priority Research Program of Chinese Academy of Sciences (Grant No. XDB26000000), and the Fundamental Research Funding of State Key Laboratory of Palaeobiology and Stratigraphy, Nanjing Institute of Geology and Palaeontology, Chinese Academy of Sciences (Grant No. 20172106).

\section{Availability of data and materials}

All data generated or analyzed during this study are included in this published article.

\section{Ethics approval and consent to participate}

Not applicable.

\section{Consent for publication}

Not applicable.

\section{Competing interests}

The authors declare that they have no competing interests.

\section{Author details}

${ }^{1}$ State Key Laboratory of Systematic and Evolutionary Botany, Institute of Botany, Chinese Academy of Sciences, Beijing 100093, China. ${ }^{2}$ State Key
Laboratory of Palaeobiology and Stratigraphy, Nanjing Institute of Geology and Palaeontology and Center for Excellence in Life and Paleoenvironment, Chinese Academy of Sciences, Nanjing, Jiangsu Province 210008, China. ${ }^{3}$ Division of Paleontology, Institute of Geosciences, University of Bonn, Nussallee 8, 53115 Bonn, Germany. ${ }^{4}$ Huntington Botanical Gardens, 1151 Oxford Road, San Marino, California 92208, USA. ${ }^{5}$ School of Chemical, Biological and Environmental Sciences, Yuxi Normal University, Yuxi 653100, Yunnan Province, China.

Received: 8 June 2019 Accepted: 30 September 2020 Published online: 12 November 2020

\section{References}

1. Chen J-R, Ding B-Y, Funston AM. Trapaceae. In: Wu Z-Y, Raven PH, Hong DY, editors. Flora of China, vol. 13. Beijing: Science Press \& St. Louis: Missouri Botanical Garden Press; 2007. p. 290-1.

2. Graham SA. Fossil records in the Lythraceae. Bot Rev. 2013;79:48-145.

3. Mohr BAR, Gee CT. Sporotrapoidites erdtmanii (Nagy) Nagy, a trapaceous pollen species pertaining to the Oligocene to Pliocene genus Hemitrapa Miki. Grana. 1990;29(4):285-93.

4. Zetter R, Ferguson DK. Trapaceae pollen in the Cenozoic. Acta Palaeobotanica. 2001;41:321-39.

5. Cronquist A. An integrated system of classification of flowering plants. New York: Columbia University Press; 1981.

6. Takhtajan AL. Diversity and classification of flowering plants. New York: Columbia University Press; 1997.

7. Takhtajan AL. Outline of the classification of flowering plants (Magnoliophyta). Bot Rev. 1980;46(3):225-359.

8. Miki S. Trapa of Japan with special reference to its remains. J Inst Polytech Osaka City Univ Ser D Biol. 1952;3:1-29.

9. Miki S. Evolution of Trapa from ancestral Lythrum through Hemitrapa. Proceed Imperial Acad Japan. 1959;35:289-94.

10. Graham SA, Hall J, Sytsma K, Shi S-H. Phylogenetic analysis of the Lythraceae based on four gene regions and morphology. Int J Plant Sci. 2005:166(6):995-1017.

11. Qin H-N, Graham S, Gilbert MG. Lythraceae. In: Wu Z-Y, Raven PH, Hong D-Y, editors. Flora of China, vol. 13. Beijing: Science Press \& St. Louis: Missouri Botanical Garden Press; 2007. p. 274-89.

12. Graham SA, Diazgranados M, Barber JC. Relationships among the confounding genera Ammannia, Hionanthera, Nesaea and Rotala (Lythraceae). Bot J Linn Soc. 2011;166(1):1-19.

13. Huang Y-L, Shi S-H. Phylogenetics of Lythraceae sensu lato: a preliminary analysis based on chloroplast $r b c L$ gene, $p s a A-y c f 3$ spacer, and nuclear rDNA internal transcribed spacer (ITS) sequences. Int J Plant Sci. 2002;163(2):21525.

14. Morris JA. A molecular phylogeny of the Lythraceae and inference of the evolution of heterostyly. Kent. dissertation: Kent State University; 2007.

15. Budantzev LJ. The waterchestnuts (Trapa and Hemitrapa) from the Tertiary deposits of the southeast coast of Lake Baikal. Botaničeskii Žurnal. 1960;45: 139-44 (in Russian).

16. Kovar-Eder J, Wójcicki JJ, Zetter R. Trapaceae from the late Miocene of Austria and the European context. Acta Palaeobotanica. 2005;45(2):165-86.

17. Miki S. On the change of flora in eastern Asia since Tertiary period. (1). The clay or lignite beds flora in Japan with special reference to the Pinus trifolia beds in Central Hondo. Japanese J Botany. 1941;11:237-303.

18. Wójcicki JJ, Song S-Y, Wang Y-F. Fossil Trapa L. of China. 1. A new locality from the Miocene of the Liang He coal mine, West Yunnan. Acta Palaeobotanica. 1999;39(1):5-14. 
19. Wójcicki JJ, Velitzelos D. Trapa kvacekii (Trapaceae), a remarkable new fossil species from the late Miocene of Greece. Acta Palaeobotanica-Krakow. 2007; 47(2):419-24.

20. Wójcicki JJ, Zastawniak E. Late Miocene Trapa L. (Trapaceae) of Sośnica (SW Poland) revisited. Acta Palaeobotanica. 2002;42(1):29-38.

21. Berry EW. Two new Tertiary species of Trapa. Torreya. 1914;14:105-8.

22. Berry EW. Flora of the Esmeralda Formation in western Nevada. Proceed United States Natl Museum. 1928;72:1-15.

23. Brown RW. Miocene leaves, fruits, and seeds from Idaho, Oregon, and Washington. J Paleontol. 1935;9:572-87.

24. Chaney RW, Axelrod DI. Miocene floras of the Columbia plateau. Part II. Systematic considerations. Carnegie Inst Wash Publ. 1959;627:135-229.

25. Knowlton FH. The fossil plants of the Payette Formation. United States Geological Survey, 18th annual report, part 3; 1898. p. 617-744.

26. McCartan L, Tiffney BH, Wolfe JA, Ager TA, Wing SL, Sirkin LA, Ward LW, Brooks J. Late tertiary floral assemblage from upland gravel deposits of the southern Maryland coastal plain. Geology. 1990;18:311-4.

27. Wang Q. Fruits of Hemitrapa (Trapaceae) from the Miocene of eastern China, their correlation with Sporotrapoidites erdtmanii pollen and paleobiogeographic implications. J Paleontol. 2012;86(1):156-66.

28. Wójcicki JJ, Wilde V. A new species of Trapa (Trapaceae) from the Pliocene of the Zennern depression, near Fritzlar (Hesse, Germany). Senckenb Lethaea. 2001;81(1):17-23.

29. No. 2 Regional Geological Survey Team, Hebei Bureau of Geology and Mineral Resources: Qipanshan section (K-50-16), regional geological survey $(1: 200,000)$ of the People's Republic of China (in Chinese); 1979.

30. Li J-F, Ferguson DK, Yang J, Feng G-P, Ablaev AG, Wang Y-F, Li C-S. Early Miocene vegetation and climate in Weichang District, North China. Palaeogeogr Palaeoclimatol Palaeoecol. 2009;280(1):47-63.

31. Saporta G. Essai descriptif sur les plantes fossiles des Arkoses de Brives près le Puy-en-Velay. Typographie et litographie M-P Marchessou, Le Puy. Ann Soc Agric Arts et Commerce du Puy. 1878;33:1.

32. Boulay N. Flore fossile de Gergovie. Annales de la Société Scientifique de Bruxelles. 1899;23:55-78.

33. Mai DH, Walther H. Die oligozänen und untermiozänen Floren NordwestSachsens und des Bitterfelder Raumes. Abhandlungen des Staatlichen Museums für Mineralogie und Geologie zu Dresden. 1991;38:1-230.

34. Wójcicki J, Kvaček Z. The earliest fossil record of the Trapaceae in Europe from the late Eocene diatomite of Kučlín, North Bohemia. Phytologia Balcanica. 2003:9(2):165-74

35. Mai DH. Entwicklung der Wasser- und Sumpfpflanzen-Gesellschaften Europas von der Kreide bis ins Quartär. Flora. 1985;176(5-6):449-511.

36. Wójcicki JJ, Zastawniak E. The Trapaceae family in the Tertiary of Europe-preliminary results. Botanical Guidebooks. 2003;26:153-85.

37. Su T, Li S-F, Tang H, Huang Y-J, Li S-H, Deng C-L, Zhou Z-K. Hemitrapa Mik (Lythraceae) from the earliest Oligocene of southeastern Qinghai-Tibetan plateau and its phytogeographic implications. Rev Palaeobot Palynol. 2018; 257:57-63.

38. Golovneva L. The new genus Palaeotrapa (Trapaceae?) and new species Quereuxia from the Rarytkin series (the Koryak upland, the MaastrichtianDanian). Botanical J. 1991;76:601-9 (in Russian).

39. Sun G, Zheng S, Dilcher DL, Wang Y, Mei S. Early angiosperms and their associated plants from western Liaoning, China. Shanghai: Shanghai Scientific and Technological Education Publishing House; 2001.

40. Vassiljev VN. A new genus of Trapaceae. Palaeontological J. 1967;2:107-12 (in Russian).

41. Sun G, Dilcher DL, Wang $H$, Chen Z. A eudicot from the Early Cretaceous of China. Nature. 2011;471(7340):625-8.

42. Wu Z-Y, Raven PH, Hong D-Y. Flora of China illustrations, Vol. 13, Clusiaceae through Araliaceae. Beijing: Science Press \& St. Louis: Missouri Botanical Garden Press; 2008.

43. Fu D-Z, Les DH. Ceratophyllaceae. In: Wu Z-Y, Raven PH, Hong D-Y, editors. Flora of China, vol. 6. Beijing: Science Press \& St. Louis: Missouri Botanical Garden Press; 2001. p. 121-2.

44. Ho T-N, Ornduff R. Menyanthaceae. In: Wu Z-Y, Raven PH, Hong D-Y, editors. Flora of China, vol. 16. Beijing: Science Press \& St. Louis: Missouri Botanical Garden Press; 1995. p. 140-2.

45. Mao L, Foong SY. Tracing ancestral biogeography of Sonneratia based on fossil pollen and their probable modern analogues. Palaeoworld. 2013;22(3): 133-43.
46. Li C-K. A Tertiary beaver from Changpei, Hopei Province. Vertebrata Palasiatica. 1962;6(1):72-9. (in Chinese with English abstract).

47. Guo C, Yao J, Wu P, Li C. Early Miocene mosses from Weichang, North China, and their environmental significance. Acta Geologica Sinica (English Edition). 2013;87(6):1508-19.

48. Li Y, Yi T-M, Li Y-Z, Li C-S. Spirematospermum wetzleri (Heer) Chandler (Zingiberaceae) from the Miocene of Weichang, Hebei Province, North China and the phytogeographic history of the genus. J Palaeogeogr. 2018;7: 7.

49. Liang X-Q, Li Y, Kvaček Z, Wilde V, Li C-S. Seeds of Weigela (Caprifoliaceae) from the Early Miocene of Weichang, China and the biogeographical history of the genus. Taxon. 2013;62(5):1009-18.

50. Liang X-Q, Wilde V, Ferguson DK, Kvaček Z, Ablaev AG, Wang Y-F, Li C-S. Comptonia naumannii (Myricaceae) from the early Miocene of Weichang, China, and the palaeobiogeographical implication of the genus. Rev Palaeobot Palynol. 2010;163(1):52-63.

51. Lu P, Li Y, Zhang J-W, Liang X-Q, Li Y-Z, Li C-S. Fruits of Scirpus (Cyperaceae) from the early Miocene of Weichang, Hebei Province, North China and their palaeoecological and palaeobiogeographical implications. J Palaeogeogr. 2019;8(2):142-9.

52. Leclercq $\mathrm{S}$. Refendage d'une roche fossilifère et dégagement de ses fossiles sous binoculaire. Senckenb Lethaea. 1960:41:483-7.

53. Swofford DL. PAUP* 4.0a165: phylogenetic analysis using parsimony (and other methods). Sinauer, Sunderland, Massachusetts, USA; 2002.

\section{Publisher's Note}

Springer Nature remains neutral with regard to jurisdictional claims in published maps and institutional affiliations.
Ready to submit your research? Choose BMC and benefit from:

- fast, convenient online submission

- thorough peer review by experienced researchers in your field

- rapid publication on acceptance

- support for research data, including large and complex data types

- gold Open Access which fosters wider collaboration and increased citations

- maximum visibility for your research: over $100 \mathrm{M}$ website views per year

At $\mathrm{BMC}$, research is always in progress.

Learn more biomedcentral.com/submissions 